Journal homepage: www.aesacademy.org

\title{
Economics of production and marketing of natural rubber (Hevea brasiliensis) in Jhapa, Nepal
}

\author{
Subodh Raj Pandey ${ }^{1^{*}}$ (D) , Surya Mani Dhungana ${ }^{2}$ and Govinda Prasad Sharma ${ }^{3}$ \\ ${ }^{1}$ Agriculture and Forestry University, Rampur, Chitwan, NEPAL \\ ${ }^{2}$ Department of Agricultural Economics and Agribusiness Management, Agriculture and Forestry University, NEPAL \\ ${ }^{3}$ Ministry of Agriculture and Livestock Development, NEPAL \\ *Corresponding author's E-mail: timsubodh13@gmail.com
}

\section{ARTICLE HISTORY}

Received: 22 January 2020

Revised received: 29 February 2020

Accepted: 13 March 2020

\section{Keywords}

Financial feasibility

Marketing

Natural rubber

Price spread

Production

\section{ABSTRACT}

A study was carried to assess the production and marketing status of natural rubber in Jhapa district in 2019, from a random sample of 70 households and 5 traders. Results were drawn using descriptive and inferential statistics employing SPSS and MS-Excel. The average area under natural rubber cultivation was 2.2 bigha and the productive area was 1.21 bigha. The average rubber sheet produced per household was $1167.092 \mathrm{~kg}$ and average yield was found to be $958.77 \mathrm{~kg} / \mathrm{bigha}$ in the study area. The average annual household income from natural rubber was found to be NRs. 233418.57 which contributes 58.54 percent in the total household income. Three marketing channels were identified and the price spread ranged from NRs. 20 to 40 . The producers' share in consumers' price ranged from $81.82 \%$ to $90.91 \%$. The major production problem identified was the lodging by wind (0.80) and the major marketing problem faced by producers and traders was the absence of grading facility (0.82). Rubber farms were found to be a profitable farm enterprise with a discounted benefit-cost ratio of 1.88. The calculated NPV was 410992.40 , IRR was $22 \%$ and PBP was 8.52 years respectively denoting the sustainability of rubber cultivation. RRIM 600, RRII 105 and GT1 were the major growing varieties of rubber in the study area. The cost of establishment in the first year (48.702\%) is highest compared to the following years. The selling price of latex and sheet was found higher in 2015 and 2016 with a reduction of price in 2017 due to the high import of Indonesian rubber sheet. This research tries to present the general idea on the overall production and marketing status in the study area.

(C)2020 Agriculture and Environmental Science Academy

Citation of this article: Pandey, S.R., Dhungana, S.M. and Sharma, G.P. (2020). Economics of production and marketing of natural rubber (Hevea brasiliensis) in Jhapa, Nepal. Archives of Agriculture and Environmental Science, 5(1): 25-32, https://dx.doi.org/10.26832/24566632.2020.050104

\section{INTRODUCTION}

Rubber Plant (Hevea brasiliensis) is the perennial crop and the natural source of rubber. There are 79 families, 311 genera and 2000 species associated with natural rubber production. The various species associated with rubber production are Hevea brasiliensis, Parthenium argentatum, Ficus elastica, Manihot glaziovii, Taraxacum kok-saghyz etc. Among them, Havea brasilinesis is best for extraction of latex. The rubber holds the $3^{\text {rd }}$ largest position of the world industry after iron and steel. About 20 million of the world populations are directly dependent upon rubber for the source of income. About 400 types of surgical equipment and 50,000 types of other equipment are prepared from the synthetic and natural rubber. The synthetic rubber is prepared from the remains of petroleum products (RRII, 1980). Economic and socio-politics in the world, currency exchange and speculation of rubber market influence the price of the rubber (Ismail and Aziz, 2018). Nepal imported rubber and articles thereof of NRs. 8,307,815,000 and export of NRs. 18,207,000 per annum (MoAD, 2017) with a trade deficit of NRs. $8,289,608,000$ in the FY 2016/2017 (MoF, 2018). Prime Minister Agriculture Modernization Project (PMAMP), Project 
Implementation Unit, Rubber zone, Jhapa is responsible for uplifting the standard of rubber cultivation in Nepal (NPC, 2003). These plants have 30 years of economic life but may live up to 100 years or even more than that. The plantation would start yielding from the $5-6^{\text {th }}$ year onwards. The natural rubber (latex) is processed to convert into a storable and marketable form. The height of the rubber plant is about $30 \mathrm{~m}$. They have trifoliate leaves and are pollinated by insects. The 3 budded seed can burst up to $15-18 \mathrm{~m}$. The latex can be extracted from any parts of the plant but the high amount can be extracted from the trunk.

The area under rubber cultivation is limited to four districts of Nepal namely Jhapa, Morang, Sunsari, Illam. The market for natural rubber in developed countries is mostly saturated and is not expected to grow in the future, but it is expanding in the nations of "New Asia", which includes India, Asian countries and especially China (Manivong, 2007). To achieve a high yield of rubber latex, good variety, high fertility of the soil and appropriate cultural management both in the immature and tapping stage are important (Onthong, 2015). The favourable condition required for rubber farming includes the height of 450 masl, 5$15^{\circ}$ elevation, the temperature of $21^{\circ} \mathrm{C}$ to $28^{\circ} \mathrm{C}$ (due to the agro -ecological diversity $29^{\circ}-30^{\circ} \mathrm{C}$ was also found better in Nepal), the relative humidity of $70-95 \%$, rainfall of $2000-3000 \mathrm{~mm}$ and $\mathrm{pH}$ of 4-6.5. Areas within 8 degrees north of the equator, 10 degrees south of the equator, high temperature, altitude below $400 \mathrm{~m}$ and high humidity are the ideal conditions for the natural rubber-producing plant (Yogish, 2017).

The history of natural rubber cultivation started from 2046 B.S. with the establishment of Gorakhkali Rubber Udyog Ltd. (estd. in 2041 B.S.) in Deurali, Gorkha by the aid of the Chinese Government. It had an objective of import substitution by the production of raw materials required for the industry. The contract was done with Sudha Fal Ras, Sanishare, Jhapa to trial rubber cultivation in 5 ha in 2047 B.S. The task force was formed with the co-ordination between Ministry of Agriculture and Gorakhali Rubber Udyog in 2050 B.S. The rubber development committee was established in the same year. The Indian team gave the highly optimistic note on the promising potential of rubber cultivation in Jhapa, Morang, Sunsari and Illam of Nepal (Khanal, 2003). Crop development division under Department of agriculture was given the role for rubber upliftment in 2052 B.S. Crop development directorate started subsidy for the rubber co-operatives in 2061 B.S. The Institute of Rubber and Jatropha Research Institute-Nepal was established in 2067 B.S. by non-resident Nepalese of America. Small farmers natural rubber producer's association, Jhapa and Natural rubber farmer's cooperative organization, Buddhasanti was established in 2069 B.S. and 2071 B.S. respectively. Rubber zone was established in 2075 B.S. The task force was again formed in 2075 B.S. to study the possible expansion of rubber in the eastern part of Nepal (Jhapa, Morang, Sunsari, Illam, Saptari and Udyapur) which gave the promising result of the probable expansion of 20,400 ha. The expansion includes 8000 ha, 4900 ha, 2000 ha, 1500 ha, 500 ha and 1000 ha in Jhapa, Morang, Sunsari, Illam,
Saptari and Udhayapur, respectively. The rubber cultivation has now expanded to Jhapa, Morang, Sunsari and southern part of Illam. There are no formal details on the number of rubber farmers and coverage of rubber plant in Nepal. The varieties grown in Nepal are Rubber Research Institute of India (RRII) 105, Rubber Research Institute of Malaysia (RRIM) 600 and Godang Tapen (GT) 1. This study will help students, stakeholders, farmers and policymakers to get knowledge on the general overview of production and marketing status of natural rubber.

\section{MATERIALS AND METHODS}

\section{Study area}

For this study, Jhapa district was purposively selected as it is one of the important districts in terms of rubber cultivation and a sole prioritized district by PMAMP. The district lies in the $26.20^{\circ}$ to $26.50^{\circ} \mathrm{N}$ latitude and $87.39^{\circ}$ to $88.12^{\circ} \mathrm{E}$ longitude with1606 square $\mathrm{km}$ of land. It is located in the southeastern part of Nepal with estimated rubber cultivated area of 311 hectares as registered by PMAMP-Rubber zone, Jhapa (MoAD, 2017).

\section{Sample size and sampling procedure}

The simple random sampling design was adopted to select municipalities, rural municipalities, villages and farmers. Altogether 70 farm households were selected among 6 municipalities (Birtamoad, Dhamak, Mechinagar, Bhadrapur, Kankai and Arjundhara) and 3 rural municipalities (Kechanakawal, Barhadashi and Buddhashanti) (PMAMP-Rubber zone, 2019). An available roster at PMAMP zone office was used to select the farmers.

\section{Data collection techniques}

Household survey: The household survey was conducted employing interview technique using a pre-tested semi-structured questionnaire. All selected farmers aged 25 and above were interviewed for primary data collection. The interview was taken carefully to generate more realistic, reliable and complete responses. Respondents were interviewed with questions seeking demographic, educational, sociocultural, behavioural, economic and other information regarding production and marketing of natural rubber.

Focus group discussions (FGDs): A total of 3 focus group discussions were conducted with farmer leaders and active commercial farmers by using a standard checklist. The information obtained from focus group discussions were used to supplement and verify the data collected from the household survey. FGD also enabled to generate alternative data beyond the questionnaire survey.

Key informant interview (KII): The key informant used in the survey included the important stakeholders of the study area such as local leaders, extension workers, heads and executive 
member of farmer groups and cooperatives, heads of community-based organizations, etc. Key informants were interviewed using an interview checklist and the information obtained was used in verifying the information obtained from the household survey.

Case study: A case study of a typical natural rubber farmer of the study area was conducted for an in-depth search of all relevant information. Farmer's perception, decision making, technology adoption, package of practice, social organization, gender roles, production and marketing economics and its impacts on rural livelihood was studied.

Field observation and verification: Field observation was done at different times to witness the situation, which was assistive to validate the information received from the household survey.

\section{Data and data types}

Both quantitative and qualitative information regarding objectives were gathered using primary and secondary sources.

Primary data: The study was based on primary data. Primary data were obtained from the selected farmers through a personal interview during 2019 using a pre-tested and structured questionnaire. The questionnaire was developed to generate information regarding preparation of land, seeds, costs incurred on the purchase of various inputs, total production and its costs, price and marketing of rubber. The questionnaire was pretested before final administration. The collected data were crosschecked and confirmed from key informants interview, direct observation, and individual interview.

\section{Secondary data}

Secondary data was collected from district profile, journals, research articles, thesis, MoALD website, FAO website, Central Bureau of Statistics (CBS), Krishi diary, PMAMP zone profile etc. The secondary data was generated and tabulated elsewhere possible and used in further analysis to find out the appropriate finding.

\section{Data analysis technique}

Data coding, entry and cleaning: The collected data were coded and entered in Statistical Package for Social Science (SPSS). The data was further cleaned by removing errors, inconsistencies and overlapped responses using SPSS. The data was analyzed using SPSS and Ms-excel.

Qualitative data analysis: The qualitative data were further quantified to carry out the quantitative analysis.

Quantitative data analysis: The collected quantitative data were analyzed using both descriptive and analytical analysis.
Economics of rubber production: Rubber is a perennial crop which can be economically cultivated up to 30 years. The gestation period is six to seven years. From the seventh year onwards, it will start yielding which can be realized after 12 years.

Establishment cost: The cost incurred for establishing and maintaining the rubber orchards up to the bearing age was considered as establishment cost. It was calculated at current factor prices. Establishment cost included the expenditure on material cost and labour cost.

Yields and returns: Yield and returns were calculated per bigha basis. Prices received for rubber at the time of data collection was considered to compute the incomes from farms.

Benefit-cost ratio: It was taken as the ratio of the present worth of incremental benefit stream (cash inflow) to present worth of incremental cost stream (cash outflow) for the enterprise.

$$
\text { Discounted BC Ratio }=\frac{\sum_{\mathrm{t}=1}^{\mathrm{n}} \frac{\mathrm{B}_{\mathrm{t}}}{(1+\mathrm{i})^{\mathrm{t}}}}{\sum_{\mathrm{t}=1}^{\mathrm{n}} \frac{\mathrm{C}_{\mathrm{t}}}{(1+i)^{\mathrm{t}}}}
$$

Where,

$B_{t}$ : incremental benefit in $t^{\text {th }}$ period due to farm enterprise

$\mathrm{C}_{\mathrm{t}}$ : incremental cost in $\mathrm{t}^{\text {th }}$ period due to farm enterprise

$\mathrm{n}$ : number of years

i: interest rate

Keeping farm enterprise by the farmer will be financially feasible if the present worth of incremental benefits is greater than the present worth of the incremental cost or in other words, B-C ratio exceeds one.

Net present value (NPV): It is used as a discounted cash flow measure of absolute profitability. NPV is computed as present worth of incremental benefits (cash inflows) less present worth of incremental cost (cash outflows) due to farm enterprise. Positive NPV value indicates the feasibility of the business.

$$
N P V=\sum_{t=1}^{n} \frac{B_{t}-C_{t}}{(1+r)^{t}}
$$

Where,

$\mathrm{B}_{\mathrm{t}}$ : Benefit; $\mathrm{C}_{\mathrm{t}}$ : Cost; $\mathrm{t}$ : Time in years; $\mathrm{r}$ : Interest (discount rate) \%

Scaling technique: Qualitative data were taken into account to prepare the index. Based on responded frequencies, weighted indexes were calculated for the analysis of farmer's perception on the extent of production and marketing problems. Farmer's perception of the different production and marketing problems were ranked by using five-point scales. The scale value of $1,0.8$, $0.6,0.4$ and 0.2 were used to most severe, severe, moderate, serious and least serious, respectively. The index of importance was computed by using the formula: 


$$
\mathrm{I}_{\mathrm{imp}}=\sum \frac{\operatorname{SiFi}}{\mathbb{N}}
$$

Where,

I imp $_{\text {Index of importance }}$

$\Sigma$ : Summation

$\mathrm{S}_{\mathrm{i}}: \mathrm{i}^{\text {th }}$ scale value

$F_{i}$ : Frequency of $i^{\text {th }}$ importance given by the respondents

$\mathrm{N}$ : Total number of respondents

Marketing functions: The marketing channels of rubber were identified based on the data collected from intermediaries involved from the point of production (producer) to the point of ultimate consumer (industrial consumer). The costs involved in moving the rubber product from the point of production to the point of the traders is known as the cost of performing marketing functions. It involves transportation cost, weighing cost, storage cost, loading and unloading cost, packaging cost, miscellaneous cost etc.

Price spread: The price spread is the difference between the price paid by the consumer and the price received by the producer. It includes marketing costs and margins. The price spread was calculated out as:

Producer's share in Consumers' rupee $=\frac{\text { Producer's price }}{\text { Consumer'sprice }} \times 100$

To assess the marketing efficiency in the sale of the rubber, Shepherd's formula of the following form was used.

$$
M E=\frac{V}{I}-1
$$

Whereas,

ME: Marketing efficiency

$\mathrm{V}$ : Consumer price per unit of rubber sheet

I: Marketing sheet per unit of rubber sheet

\section{GRRIM $600 \quad \square$ RRII $105 \quad \square$ GT 1}

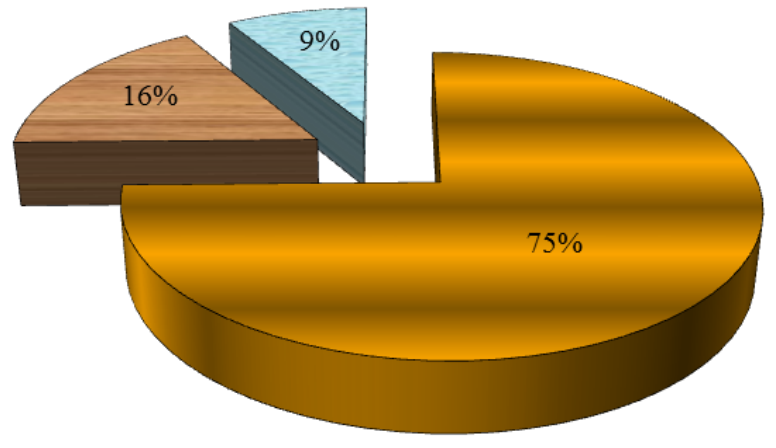

Figure 1. Area coverage by different varieties.

\section{RESULTS AND DISCUSSION}

The percentage of area covered by RRIM 600 was 75\%, RRII 105 was $16 \%$ and GT1 was $9 \%$ in the studied area (Figure 1) but RRII 105 was majorly grown in Karnataka (Yogish, 2017). The area and production of the natural rubber in the studied area is 85.21 bigha and $81696 \mathrm{~kg}$ with the productivity of $958.77 \mathrm{~kg} /$ bigha (Table 1). The productivity was found lower than that of Kerala, India (George and Chandrashekar, 2014).

Investment evaluation of rubber plantation

The data of the rubber plant was calculated on the year basis. Eight years of data were collected from the farmers and 30 years of data on the cost and yield were projected based on profit and cost. The discounted BC ratio was calculated to be 1.88. Similarly, the Net Present Value (NPV) was calculated as NRs. 410992.40. The Internal rate of return was calculated as $22 \%$. Similarly, the payback period of the rubber plantation system was found to be 8.52 years (Table 2 ). The majority of expenses in the production system is in the $1^{\text {st }}$ year of the plantation (48.702\%). International Mountain Society (2017) also reported the maximum expense in the $1^{\text {st }}$ year. Similarly, $14.567 \%$ of the expenses took place in the $2^{\text {nd }}$ year. The expenses in the $3^{\text {rd }}, 4^{\text {th }}, 5^{\text {th }}$ and $6^{\text {th }}$ year of the plantation is $8.106 \%$, $8.042 \%, 10.226 \%$ and $13.355 \%$ respectively (Table 3 ). The planting cost of the materials is very high. The ratio of material cost to labour cost is greater than 1 which means that the material cost in the establishment phase is higher than the labour cost (Table 4).

Price variability in the rubber sheet and latex

The trend analysis was conducted to find out the maximum and minimum price of rubber sheet of 5 years. There was a maximum price in 2015 . There was a decreasing trend in the price up to 2017. There was a dramatic fluctuation in the price of rubber sheet in 2017 due to the high import of Indonesian rubber in very low price but the price fluctuation in other countries such as India, China, Japan and USA depends on their production unlike Nepal (Fong et al., 2018). There is little price fluctuation in the year 2018 and 2019 (Figure 2). The trend analysis was conducted to find out the maximum and minimum price of the latex of 5 years. The latex was sold at a higher price in 2015 and 2016. The price decreased during 2017 due to the high import of rubber sheet at a low price. There is very little fluctuation in the price of the latex in 2018 and 2019 (Figure 3).

Table 1. Area, production and productivity of study area.

\begin{tabular}{ll}
\hline Particulars & Values \\
\hline Area (bigha) & 85.21 \\
Production $(\mathrm{kg})$ & 81696.79 \\
Productivity $(\mathrm{kg} /$ bigha) & 958.77 \\
\hline
\end{tabular}

Table 2. Investment appraisal of the rubber plantation system. Investment appraisal

Discounted BC ratio 1.88
NPV (NRs.) 
Table 3. Cost of establishing 1 bigha of rubber plantation.

\begin{tabular}{|c|c|c|c|c|c|c|c|c|c|}
\hline & Items & I year & II year & III year & IV year & Vyear & VI year & Total & $\begin{array}{l}\text { Percentage } \\
\text { to total cost }\end{array}$ \\
\hline$A$ & Material cost & & & & & & & & \\
\hline 1 & Planting material & 80000 & 8000 & & & & & 88000 & 28.286 \\
\hline 2 & Shading material & 8000 & 2000 & & & & & 10000 & 3.214 \\
\hline 3 & Manures and fertilizers & 12920 & 12920 & 12920 & 12920 & 17416 & 17416 & 86512 & 27.807 \\
\hline \multirow[t]{2}{*}{4} & Insecticides and Pesticides & 1300 & 1300 & 1300 & 1300 & 1300 & 1300 & 7800 & 2.507 \\
\hline & Total material costs & 102220 & 24220 & 14220 & 14220 & 18716 & 18716 & 192312 & 61.814 \\
\hline$B$ & Labour cost & & & & & & & & \\
\hline 1 & Land preparation & 3200 & 600 & & & & & 3800 & 1.221 \\
\hline 2 & Digging and pit filling & 15000 & 5000 & & & & & 20000 & 6.429 \\
\hline 3 & Planting & 8800 & 2000 & & & & & 10800 & 3.471 \\
\hline 4 & Shading & 8800 & 2500 & & & & & 11300 & 3.632 \\
\hline 5 & Weeding & 5000 & 2000 & 1500 & 800 & 600 & 500 & 10400 & 3.343 \\
\hline 6 & $\begin{array}{l}\text { Manures and fertilizer } \\
\text { application }\end{array}$ & 8000 & 8000 & 8000 & 8000 & 10000 & 10000 & 52000 & 16.714 \\
\hline \multirow[t]{4}{*}{7} & $\begin{array}{l}\text { Insecticide and Pesticide } \\
\text { application }\end{array}$ & 500 & 1000 & 1500 & 2000 & 2500 & 3000 & 10500 & 3.375 \\
\hline & Total labour costs & 49300 & 21100 & 11000 & 10800 & 13100 & 13500 & 118800 & 38.186 \\
\hline & Total cost & 151520 & 45320 & 25220 & 25020 & 31816 & 32216 & 311112 & 100.000 \\
\hline & Percentage of the total cost & 48.703 & 14.567 & 8.106 & 8.042 & 10.227 & 10.355 & 100.000 & \\
\hline
\end{tabular}

Table 4. Summary of cost of establishment of 1 bigha of rubber plantation.

\begin{tabular}{|c|c|c|c|c|c|}
\hline Year & Labour cost & Material cost & $\begin{array}{l}\text { Ratio of material cost } \\
\text { to labour cost }\end{array}$ & Total cost & $\begin{array}{l}\text { Percentage of the } \\
\text { total cost }\end{array}$ \\
\hline 1 & 49300 & 102220 & 2.073 & 151520 & 48.702 \\
\hline II & 21100 & 24220 & 1.147 & 45320 & 14.567 \\
\hline III & 11000 & 14220 & 1.292 & 25220 & 8.106 \\
\hline IV & 10800 & 14220 & 1.316 & 25020 & 8.042 \\
\hline V & 13100 & 18716 & 1.428 & 31816 & 10.226 \\
\hline VI & 13500 & 18716 & 1.386 & 32216 & 10.355 \\
\hline Total & 118800 & 192312 & & 311112 & 100 \\
\hline $\begin{array}{l}\text { Percentage of the } \\
\text { total cost }\end{array}$ & 38.185 & 61.814 & & & \\
\hline
\end{tabular}

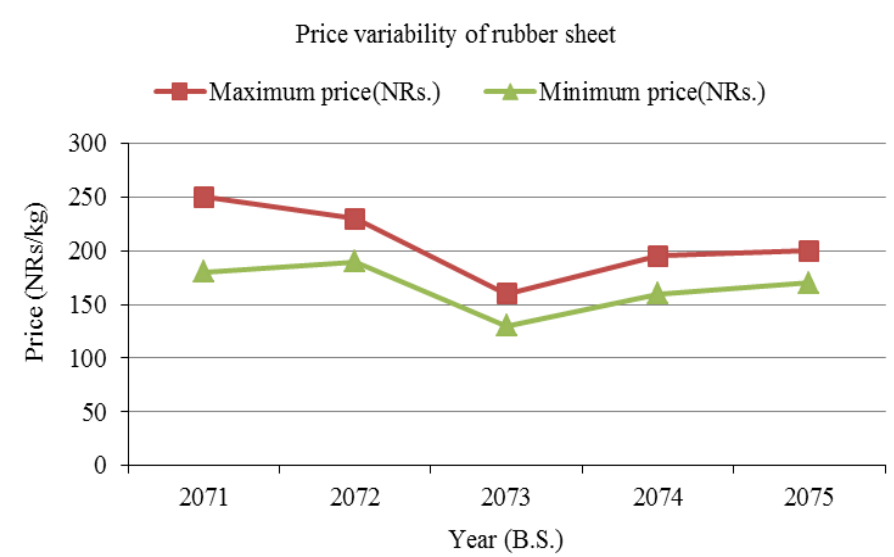

Note: 2071 B.S.=2015 A.D., 2072 B.S.=2016 A.D., 2073 B.S.=2017 A.D., 2074 B.S. $=2018$ B.S. and 2075 B.S.=2019 A.D.

Figure 2. Price variability of rubber sheet.

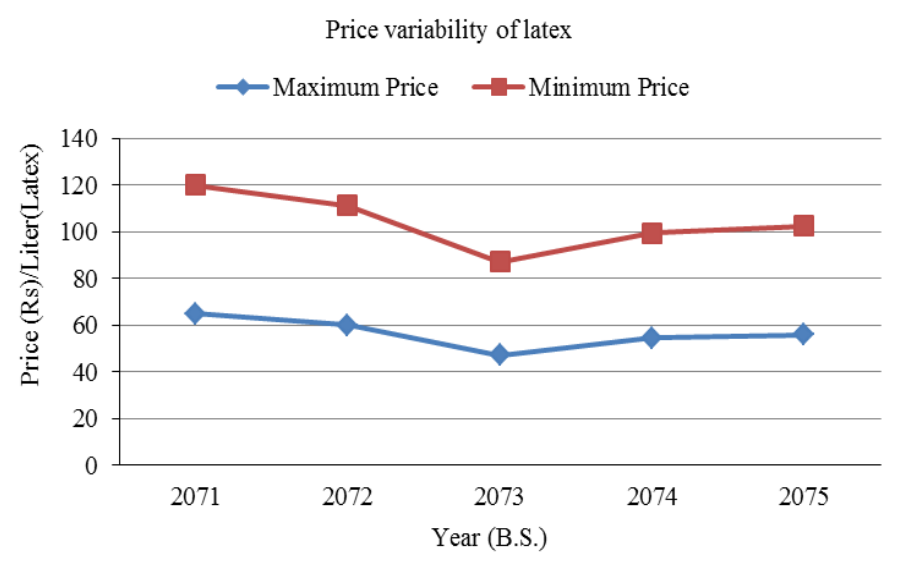

Note: 2071 B.S.=2015 A.D., 2072 B.S.=2016 A.D., 2073 B.S.=2017 A.D., 2074 B.S. $=2018$ B.S. and 2075 B.S. $=2019$ A.D.

Figure 3. Price variability of latex. 
Table 5. Ranking of pre-production problems.

\begin{tabular}{llcc}
\hline S.N. & Pre-production Problems & Index & Ranking \\
\hline 1 & Lack of technical knowledge & 0.36 & V \\
2 & Lack of saplings & 0.49 & IV \\
3 & Inability to distinguish the variety & 0.60 & III \\
4 & Lodging & 0.80 & I \\
5 & Delayed return & 0.73 & II \\
\hline
\end{tabular}

Table 6. Ranking of production problems.

\begin{tabular}{llcc}
\hline S.N. & Production Problems & Index & Ranking \\
\hline 1 & Lack of skilled manpower & 0.713 & $\mathrm{II}$ \\
2 & Lack of processing facilities & 0.593 & III \\
3 & Lack of instruments and chemicals & 0.530 & IV \\
4 & Wind & 0.823 & $\mathrm{I}$ \\
5 & Disease & 0.34 & $\mathrm{~V}$ \\
\hline
\end{tabular}

Table 7. Ranking of marketing problem faced by producers.

\begin{tabular}{lllc}
\hline S.N. & Marketing Problems & Index & Ranking \\
\hline 1 & Price fluctuation & 0.743 & $\mathrm{II}$ \\
2 & Absence of grading & 0.820 & $\mathrm{I}$ \\
3 & Delayed payment to the farmers & 0.567 & $\mathrm{IV}$ \\
4 & Traders offer low price & 0.573 & $\mathrm{III}$ \\
5 & Inadequate storage facilities & 0.297 & $\mathrm{~V}$ \\
\hline
\end{tabular}

Table 8. Ranking of marketing problems faced by traders.

\begin{tabular}{llcc}
\hline S.N. & Traders Marketing Problems & Index & Ranking \\
\hline 1 & Seasonal supply & 0.48 & $\mathrm{IV}$ \\
2 & Undried raw materials & 0.64 & $\mathrm{III}$ \\
3 & Lack of sufficient production & 0.72 & $\mathrm{II}$ \\
4 & Difficulty in transportation & 0.40 & $\mathrm{~V}$ \\
5 & Ungraded goods & 0.76 & $\mathrm{I}$ \\
\hline
\end{tabular}

Problems in natural rubber farming

Several problems hinder the production and marketing of the natural rubber. Major problems in production and marketing of rubber were identified and analyzed separately which are given below:

Pre-production and production problems

Five major problems in rubber production were identified from focus group discussion, key informants survey and field visits. Farmers were asked to rank these problems based on severity. Five-point scaling technique $(1,0.8,0.6,0.4$ and 0.2$)$ was used to measure the relative severity of those production problems. Lodging by the wind before economic life was identified as the most severe problem in rubber cultivation with the index value of 0.953 . The heavy wind during March and April was reported to lodge the rubber plant. It takes about 5-6 years to reach economic life, so delayed return was identified as the second most severe problem with an index value of 0.73 . The $3^{\text {rd }}, 4^{\text {th }}$ and $5^{\text {th }}$ severe problem identified were inability to distinguish variety (0.60), lack of sufficient saplings (0.49) and lack of technical knowledge (0.36) (Table 5). Umar et al. (2011) identified that the replacement of natural rubber by synthetic rubber, as the major threat in African countries.

There were various production problems identified in the rubber farming system, the wind was identified as major production problem with the index of 0.823 . Similarly, the $2^{\text {nd }}$ most severe problem identified was the lack of skilled manpow- er with an index of 0.713 . The $3^{\text {rd }}, 4^{\text {th }}$ and $5^{\text {th }}$ severe problem identified were lack of processing facilities, lack of instruments and chemicals and diseases with the index of $0.593,0.530$ and 0.34 respectively (Table 6). Sriyalatha (2018) identified the absence of technical knowledge as one of the major problems in small farmers in Kalutara district of Sri Lanka.

\section{Marketing problems}

Five major marketing problems faced by producers and traders in rubber farming were identified and five-point scaling technique (1, 0.8, 0.6, 0.4 and 0.2) was used to rank the seriousness of those problems. The most severe marketing problem faced by the producers was identified as the absence of grading with the index of 0.820 . The $2^{\text {nd }}$ most severe problem was identified as price fluctuation with an index of 0.743 . Similarly, the $3^{\text {rd }}, 4^{\text {th }}$ and $5^{\text {th }}$ problem were identified as trader offer low price, delayed payment to the farmers and inadequate storage facilities with the index value of $0.573,0.567$ and 0.297 respectively (Table 7) but Kerala, India faced the problem of reduced productivity due to reduced farm sizes (Kannan, 2013).

The most severe marketing problem faced by the traders was ungraded goods with an index of 0.76 . Due to the inability to grade the rubber sheets, the factories don't offer enough prices as regulated by the international market. The $2^{\text {nd }}$ most serious problem identified as lack of sufficient production (0.72), undried raw materials (0.64), seasonal supply (0.48) and difficulty in transportation (0.40) as shown in Table 8. 


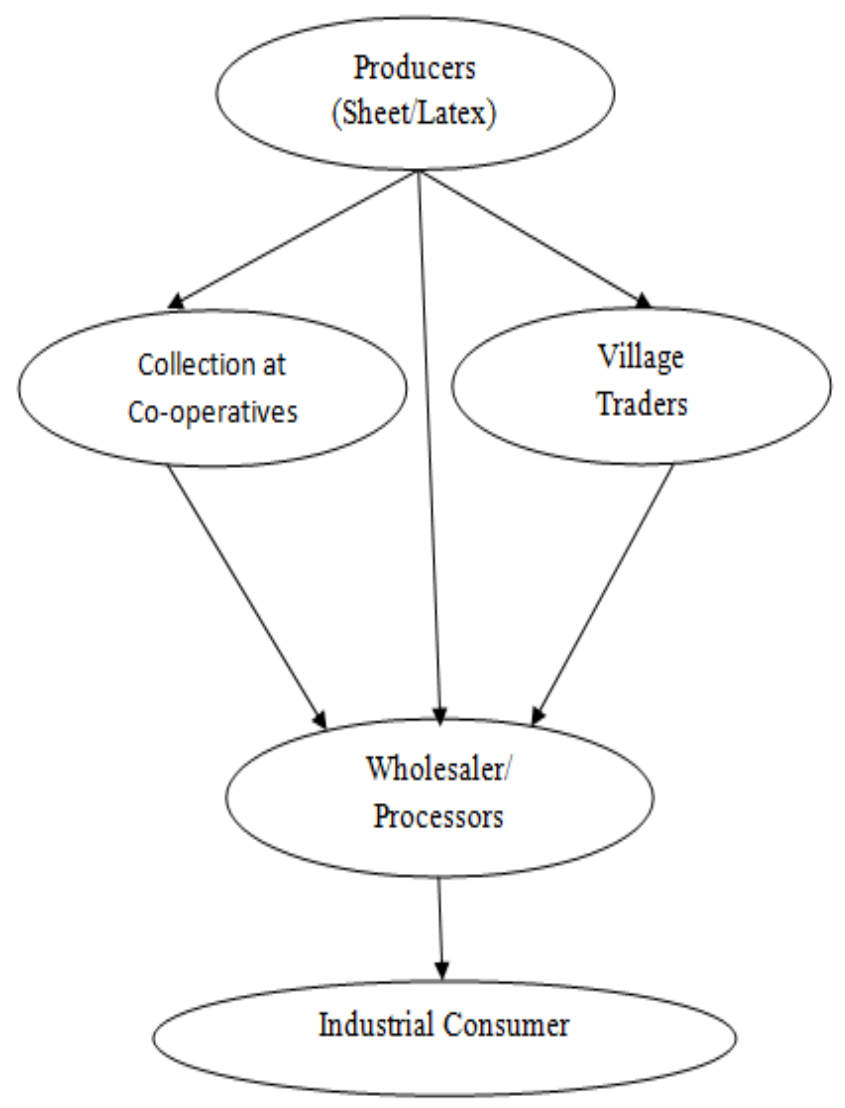

Figure 4. Marketing channel of rubber sheet/latex.

Table 9. Percentage of farmers following different marketing channels.

\begin{tabular}{lc}
\hline Marketing channels & Percentage of farmers \\
\hline Channel I & $54.28 \%$ \\
Channel II & $14.29 \%$ \\
Channel III & $31.43 \%$ \\
\hline
\end{tabular}

\section{Marketing of natural rubber}

Marketing of agriculture produce is equally important to farming for better performance (Acharya and Agarwal, 2011). A sound market is essential for promotion and commercialization of agriculture sector. The rubber sheet and latex were not directly used by the producer so the industry is considered as the consumer. The market structure in the study area is presented in Figure 4. As per the information collected from different intermediaries involved in rubber marketing, the various channels identified were:

Channel I: Producer (NRs. 195) - Wholesaler/Processors (NRs. 220) - Industrial Consumer

Channel II: Producer (NRs. 190) - Collection at Co-operatives (NRs. 195.50) - Wholesaler/Processors (NRs. 220) - Industrial Consumer

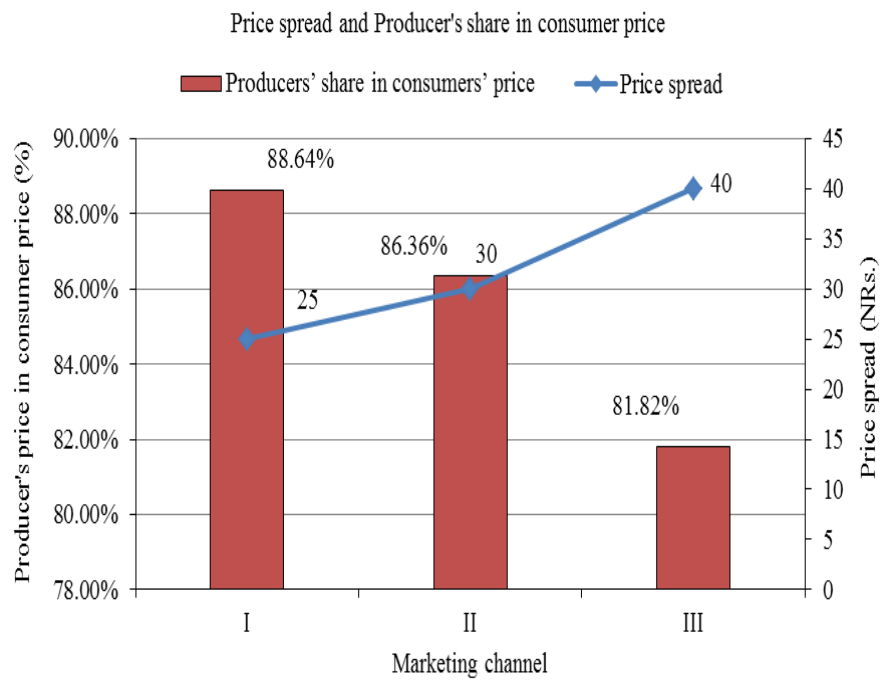

Figure 5. Price spread and producer's share in the consumer's price.

Channel III: Producer (NRs 180) - Village traders (NRs. 198) Wholesaler/Processors (NRs. 220) - Industrial Consumer

The percentage of farmers following the Channel I, Channel II and Channel III were $54.28 \%, 14.29 \%$ and $31.43 \%$ respectively (Table 9).

Marketing of rubber encompasses all the activities performed in moving the rubber sheet/latex from the point of production to the industrial consumer. Marketing system creates time, space and form utilities. The producers, cooperatives, traders, wholesalers and retailers are the main marketing actors. In the channel I, the producer receives NRs. 195, they sell their produce to the wholesaler directly. This channel has the least price spread of NRs. 25 and the producer's share in the consumer price is 88.64\%. Similarly, in channel II, The producer receives NRs. 190. They collect their produce in the co-operatives and includes only marketing cost. Then they sell their products to the wholesaler at NRs. 220. They have a price spread of NRs. 30 and have the producer's share of $86.36 \%$. In channel III, the producer receives NRs. 180 . The village trader collects and sells to the wholesaler at NRs. 198. The wholesaler sold to the industrial consumer at NRs. $220 / \mathrm{kg}$. This channel has the highest price spread of NRs. 40 and the producers' share in the consumer price is $81.82 \%$. as shown in Table 10 and Figure 5. A similar type of marketing channel was identified by Adikari and Sharma (2018) in Tripura, India. The marketing efficiency of the 3 different channels was calculated. The marketing efficiency of channel I, channel II and channel III was calculated as 10.30, 7.81 and 7.05 respectively (Table 11 ). Large companies follow the channel I, which was found more effective. Anuja et al. (2012) found a similar marketing channel. Betty et al. (2018) encouraged backwards to produce the budded stumps by themselves and process the latex to produce the maximum profit. 
Table 10. Price spread of rubber plantation through different marketing channels.

\begin{tabular}{llccc}
\hline S.N. & Particulars & Channel I & Channel II & Channel III \\
\hline 1 & Gross price received by the producer & 195 & 190 & 180 \\
2 & Marketing cost of co-operatives & - & 5.50 & - \\
3 & Price received by the cooperatives & - & 195.50 & - \\
4 & Marketing cost trader & - & - & 1.88 \\
5 & Profit of trader & - & 19.12 & 195.50 \\
6 & Wholesaler's purchase price & 19.46 & 19.46 & 19.46 \\
7 & Marketing cost of wholesalers & 5.54 & 2.04 & 220 \\
8 & Profit of wholesalers & 220 & 254 & 30 \\
9 & Industrial consumers' purchase price & 88.64 & 86.36 & 40 \\
10 & Price spread & & 81.82 \\
\hline
\end{tabular}

Table 11. Marketing efficiency of different marketing channel.

\begin{tabular}{llccc}
\hline S.N. & Particulars & Channel I & Channel II & Channel III \\
\hline 1 & Industrial consumer price & 220 & 220 & 220 \\
2 & Total marketing cost & 19.46 & 24.96 & 27.34 \\
3 & Marketing efficiency & 10.30 & 7.81 & 7.05 \\
\hline
\end{tabular}

Conclusion

The average yield in the study area was found more than that of the national average. Rubber plantations were found to be a profitable farm enterprise and it takes about three years after the production phase to cover the investment. The selling price of latex and sheet was found higher in 2015 and 2016 with the reduction of price in 2017. The price increased in the year 2018 and 2019. The producers following the market channel I was more profitable than the producers following other marketing channels.

\section{ACKNOWLEDGEMENTS}

We want to express our special thanks to Agriculture and Forestry University, Rampur, Chitwan and PMAMP, Project Implementation Unit, Rubber zone, Jhapa for this opportunity. We want to acknowledge Mr. Shesh Raj Poudel, Senior Agricultural Officer, PMAMP, Rubber zone for his guidance and support in the entire research period. We want to express our special thank to National Youth Council (NYC) for providing fund to complete this research.

Open Access: This is an open access article distributed under the terms of the Creative Commons Attribution 4.0 License, which permits unrestricted use, distribution, and reproduction in any medium, provided the original author(s) if the sources are credited.

\section{REFERENCES}

Acharya, S.S. and Agarwal, N.L. (2011). Agricultural marketing in India (5th ed.). New Delhi: Oxford and IBH Publishing Company.

Adikari, S.B. and Sharma, A. (2018). Marketing Pattern of Rubber Plantation in Tripura, India. International Journal of Current Microbiology and Applied Sciences, 7(6): 847-853.

Anuja, A.R., Kar, A., Mathur, V.C., Jha, G.K. and Kumar, P. (2012). Economic Scenario of Natural Rubber Production and Marketing in Kerala. Economic Affairs, 57(4): 415-425.

Betty, A. N., A.i, A. and E.o., A. (2018). Natural Rubber value chains: A gamechanger for smallholders. $30^{\text {th }}$ International Conference of Agricultural Economists (pp. 1-34). Vancouver: International Conference of Agricultural Economists.
Fong, Y.C., Khin, A.A. and Lim, C.S. (2018). Conceptual review and the production, consumption and price models of the natural rubber industry in selected ASEAN countries and world market. Asian Journal of Economic Modelling, 6(4): 403-413.

George, J.G. and Chandrashekar, H.M. (2014). Growth and Trends in Production and Marketing of Natural Rubber in Kerala, India. International Journal of Current Research and Academic Review, 2(8): 53-61.

International Mountain Society. (2017). The Economics of Smallholder Rubber Farming in a Mountainous Region of Southwest China: Elevation, Ethnicity and Risk. Mountain Research and Development (MRD), 37(3): 281-293.

Ismail, M.B.B. and Aziz, N.N.H.B. (2018). Economic Analysis of Rubber Production in Malaysia Using Ardl Model. International Journal of Academic Research in Business and Social Sciences, 8(5): 444-452.

Kannan, M. (2013). The Determinants of Production and Export of Natural Rubber in India. IOSR Journal of Economics and Finance (IOSR-JEF), 1(5): 41-45.

Khanal, T. (2003). Natural Rubber. Kathmandu: Gorakhali Rubber Udyog Limited, Gorkha.

Manivong, V. (2007). The Economic Potential for Smallholder Rubber Production in Northern Laos. Laos: School of Natural and Rural Systems Management.

MoAD. (2017). Project Document on Prime Minister Agriculture Modernization Project (PM-AMP). Singha Durbar, Kathmandu: Government of Nepal, Ministry of Agriculture Development.

MoAD. (2017). Statistical information on Nepalese Agriculture. Singha Durbar, Kathmandu: Ministry of Agriculture and Livestock Development.

MoF. (2018). Economic Survey 2017/18. Singha Durbar, Kathmandu: Ministry of Finance, Government of Nepal.

NPC. (2003). The Tenth Plan (PRSP) 2002-2007. Kathmandu, Nepal: HMG/N.

Onthong, J. (2015). Effect of fertilizer and dolomite applications on growth. Songklanakarin Journal of Science and Technology, 37(6): 643-650.

PMAMP-Rubber zone. (2019). Registered Rubber Gardens under private farms, cooperatives and companies. Chandragadi: Prime Minister Agriculture Modernization Project- Rubber Zone Implementation Unit, Jhapa.

RRII. (1980). Hand Book of Natural Rubber Production In India. Kottayam, India: The Rubber Research Institute of India, Rubber Board.

Sriyalatha, M.A.K. (2018). Factors Affecting Natural Rubber Production: Case Study of Small Rubber Farmers in Kalutara District, Sri Lanka. IOSR Journal of Business and Management (IOSR-JBM), 20(9): 64-73.

Umar, H.Y., Giroh, D.Y., Agbonkpolor, N.B. and Mesike, C.S. (2011). An Overview of World Natural Rubber Production and Consumption: An Implication for Economic Empowerment and Poverty Alleviation in Nigeria. Journal of Human Ecology, 33(1): 53-59.

Vinitha, A.S. and Ramalingam, L.P. (2017). Scenario of Rubber Production and Consumption in India. International Journal of Advance Research in Computer Science and Management Studies, 5(6): 34-39.

Yogish, S.N. (2017, October). Economic Analysis of Rubber Plantation-A Case Study of Shivamogga District. In Proceedings of the Sixth Middle East Conference on Global Business, Economics, Finance and Banking (ME17Dubai Conference) (pp. 1-14). 